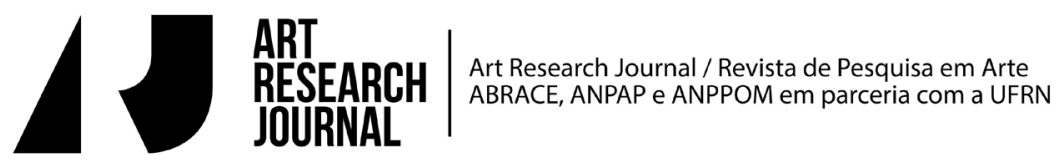

\section{Eros Volúsia \\ Performance, poéticas criativas e afirmação identitária}

\author{
Denise Mancebo Zenicola \\ Universidade Federal Fluminense \\ denisezenicola@gmail.com
}

\section{A Construção da Brasilidade}

Ao findar a Primeira Guerra Mundial (1914-1918), no Brasil, entra em decadência o maneirismo francês, na proporção direta em que começa a se pensar em nacionalismo. Um país que pouco tempo antes havia saído da escravidão, com uma mistura forçada de três raças e que apresentava diferentes áreas de desenvolvimento, oscilando entre o urbano e o rural, teria uma cultura que valesse a pena? Há, no entanto, uma concordância quanto à necessidade "de se buscar novas expressões capazes de traduzir a dinâmica da nacionalidade. Conclui-se que o país não poderia ter uma 'cara emprestada', ou uma 'cultura de empréstimo'"' (Velloso, 2000, p. 17). Nos principais centros urbanos, Rio de Janeiro e São Paulo predominantemente, diferenciada compreensão da cultura na sociedade brasileira começa a se destacar, calcada no nacionalismo. O Movimento Modernista em São Paulo, um movimento mais pensado por intelectuais e marcado pela Semana de 22, divide-se em duas alas ${ }^{1}$. A ala menos conservadora de Mario de Andrade não nega nossas raízes e nem se fecha à influência externa, pois é imperioso estabelecer uma seleção crítica nesta tarefa moderna de construir a nacionalidade. O Brasil, que ainda

\footnotetext{
${ }^{1}$ Os Modernistas acabam dividindo-se em dois grupos principais, sendo um deles mais conservador; a ala conservadora composta por Menotti del Pichia, Cassiano Ricardo, Plínio Salgado, entre outros. O outro grupo, encabeçado por Mário de Andrade, traz um elemento novo, assume o homem brasileiro, enraizado em sua cultura tropical, cabocla e mutante. Tal homem, está aberto para absorver outras culturas, porém não de forma aleatória, como vinha acontecendo até então. Numa alusão a antropofagia, este homem comeria seus "semelhantes para reter suas qualidades, uma crítica à absorção desenfreada de modelos culturais europeus" (Velloso, 2000, p. 16).
} 
apresentava preconceitos com relação a qualquer tipo de atividade manual ou corporal, ainda uma herança escravista, com o Modernismo começa a rever e mudar suas ideias. A maioria dos nossos intelectuais é forçada a reconhecer a imagem de um Brasil também negro e índio, bem como deixar de reconhecê-lo de maneira romantizada, ufanista e idealizada.

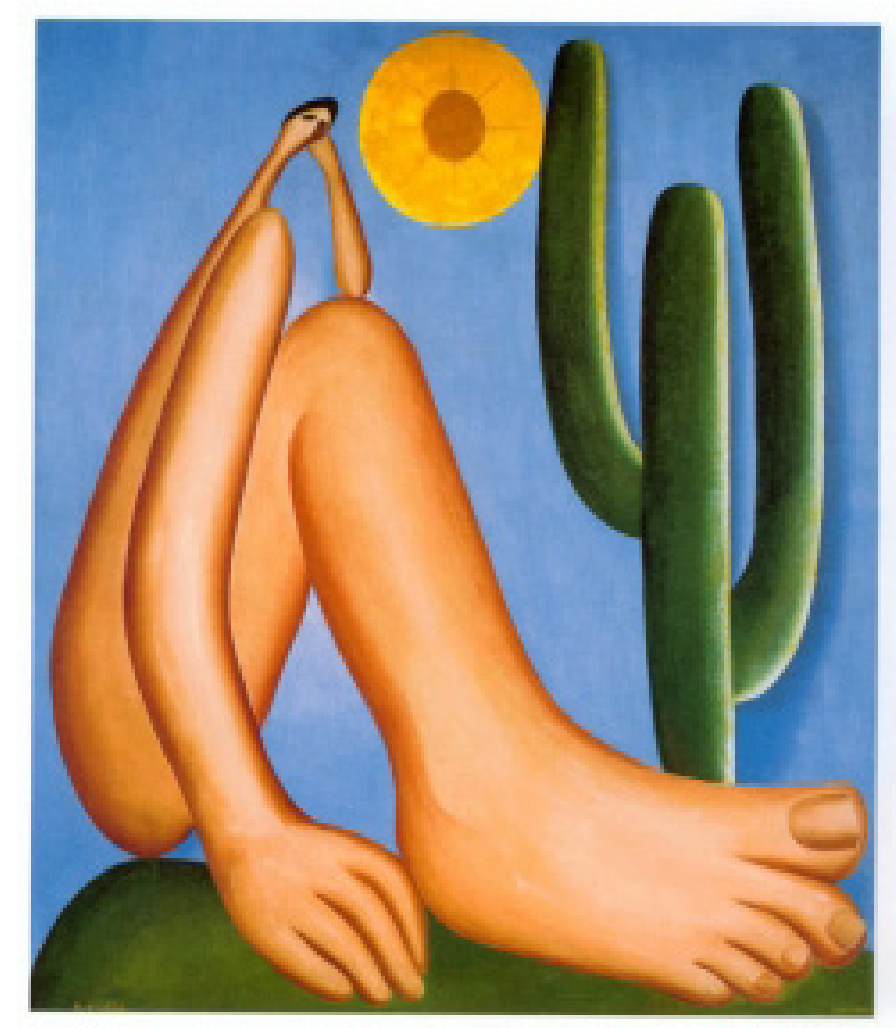

Figura 1: Abaporu, Tarsila do Amaral, óleo sobre tela, $1928 .^{2}$

No Rio de Janeiro, a reflexão sobre a identidade cultural brasileira acontece de forma diversa, não passando apenas pelas elites culturais da cidade. Uma outra tradição prevalece, com troca cultural feita nas ruas, nos cafés, nas festas de igreja, enfim, pela circulação de bens culturais, que já vinha acontecendo desde o século $\mathrm{XIX}^{3}$. O intercâmbio cultural entre intelectuais, artistas e camadas populares, na festa da Penha, Casa da Tia Ciata, bares, cafés e logradouros públicos, ocorria

\footnotetext{
${ }^{2}$ Abaporu é uma clássica pintura do modernismo brasileiro, da artista Tarsila do Amaral. O nome da obra é de origem tupi-guarani que significa "homem que come gente" (canibal ou antropófago), uma junção dos termos aba (homem), pora (gente) e ú (comer). A tela foi pintada em 1928 e oferecida ao seu marido, o escritor Oswald de Andrade. Os elementos que constam da tela, despertaram em Oswald a ideia de criação do Movimento Antropofágico.
} 
já há alguns anos trocando-se músicas, literaturas, sambas de roda e correntes de pensamento estético e cultural. Como se observa, no Rio de Janeiro, o Modernismo acontece de forma diferenciada e peculiar, com um movimento cultural das classes médias e populares urbanas, que abrange novos gêneros musicais, festas, religião, linguagem, culinária, estilo de vida e danças. Tal fenômeno, de forte influência africana, que evidencia a cultura negra urbana e ocidental, surge nas favelas e alcança a Indústria Cultural, consolidado-se nos anos 30 - a "era de redescobrimento do Brasil" (Mota, 1990, p. 38). A cultura negra pouco a pouco começa a moldar a história do Rio de Janeiro. Tal fato não acontece de maneira fácil, há resistência em aceitar a cultura negra, principalmente pela elite e boa parte da classe média carioca. No entanto, a qualidade expressiva desta cultura e sua capacidade de aglutinar cada vez mais pessoas para sua órbita são fatores determinantes neste jogo de força entre o erudito europeizado e o popular. O que se pôde observar é uma acomodação social de hábitos e costumes, nem sempre harmoniosa, como até hoje acontece. De um lado, os negros para serem aceitos na sociedade adotam alguns valores da cultura dominante e, do outro, o branco também adota certos valores da cultura negra.

A partir dos anos 40, a Capital Federal, centro de poder e das elites, começa e produzir e projetar para o país uma imagem do carioca diferenciada que agrega tanto a ideia de ser integrante do rol das nações civilizadas pretendida pelas elites, como também uma malemolência, musicalidade e humor peculiares, trazidos por este movimento cultural popular e negro. Este caldo de cultura é alimentado pelo samba que passa a ter um papel de destaque na

ideia de uma unidade nacional brasileira, difundindo o interesse pelas coisas brasileiras, ou seja, pela cultura popular depois de um tempo de coagulação nos bairros subalternos e favelas entre o povo negro e ameríndio misturado com migrantes portugueses, italianos e espanhóis (Moura, 2000, p.56).

O samba desenvolve-se na Praça Onze, a estruturação do Carnaval começa a tomar o formato atual, os programas de rádio, o milagre dos milagres da tecnolo-

\footnotetext{
3 Os espaços públicos no Rio de Janeiro desde o século XIX funcionavam como pontos de convergência - espaços dinâmicos de suporte de artes performativas. As praças e ruas tornavam-se pontos de encontros e facilitavam distintas formas de interação social entre seus frequentadores habituais, os escravos (Zenicola, 2012, p. 42).
} 
gia, o cinema falado, parques de diversão, circos, cabarés, cassinos, a dança do maxixe são coqueluches das classes remediadas e pobres, bem como os teatros de revista que motivam comportamentos, afirmam ideologias atraindo o público, tornando os artistas novos ídolos de massa, figuras modelares. Nesta troca viva de elementos culturais, observa-se o crescimento do humor através da paródia, a maior aceitação da dança, da ludicidade, características comportamentais próprias das culturas negras, um cotidiano que cruza tradições, transformações e adaptações em nome de modernismos. Segundo Saliba,

o movimento dos corpos ao apelo aos sentidos (...) a única imagem paródica possível para essa representação alternativa da República talvez tenha sido aquela cheia de movimento, de jogo, de volubilidade e, até, de sensualidade, expressa, por exemplo, na dança mais popular do Rio de Janeiro, desde o início do século: o maxixe ${ }^{4}$ (Saliba, 1998, p. 42).

Apesar de todo este movimento, as produções artísticas e culturais ainda estão restritas a um determinado público. Em função disto, segundo Ortiz, o Estado procura "estimular a cultura como meio de integração, mas sob o controle do apareIho estatal"5(Ortiz, 2008, p. 16). O Estado varguista passa a dar apoio a diversas manifestações de cunho popular como as escolas de samba e a utilizar-se do mais poderoso meio de comunicação na época, o rádio, usando, assim, estratégias para divulgar seu ideal populista nacionalista.

\begin{abstract}
É por meio do mecanismo de reinterpretação que o Estado, através de seus intelectuais, se apropria das práticas populares para apresentá-las como expressões de cultura nacional. O Candomblé, o Carnaval, os reisados, etc, são, desta forma, apropriados pelo discurso do estado, que passa a considerá-los como manifestação de brasilidade (Mota, 1990, p. 44).
\end{abstract}

\footnotetext{
${ }^{4}$ Maxixe, fruto comestível de uma planta rasteira, palavra associada, na época, a tudo o que fosse também rasteiro e de baixa categoria (Tinhorão, 1998, p. 64). A Dança do Maxixe ganha esta alcunha mas vai tornar-se a grande moda deste período.

5 "As relações entre cultura e Estado são antigas no Brasil. Nos 30, veremos que com o advento do Estado Novo, o aparecimento estatal encontra-se associado à expansão da rede das instituições culturais (criação do Serviço Nacional de Teatro), à criação de cursos de ensino superior, e também à elaboração de uma ideologia da cultura brasileira. A revista Cultura e Política foi, em 1941-1945, um órgão ideológico do Estado, no mesmo período em que o DIP exerceu suas funções de censura" (Ortiz, 2008, p. 22).
} 
Nos anos 40, já sob a influência da Segunda Guerra Mundial, estreitam-se relações entre os governos americano e ditaduras latino-americanas, a chamada política de boa vizinhança.

Neste cenário, acontece uma aproximação "de investimentos econômicos, da diplomacia e da glamourização da imagem da América Latina no cinema de Hollywood. É quando o Pato Donald vem ao Rio e conhece o Zé Carioca" (Sevcenko, 1998, p. 159). Zé Carioca, um pequeno periquito criado por Walt Disney nesta época, é um personagem galante, bem humorado, trajando paletó e de fala macia, usa chapéu e guarda-chuva e tem a ginga ${ }^{6}$ no andar e maciez no falar. Zé Carioca namora Rita, personagem morena de longos cabelos ondulados que apresenta-se vestida de rumbeira ou baiana, uma boneca que teve suas características de performance corporal copiadas de Eros Volúsia (1914-2014). É interessante ressaltar que a dança neste contexto, vivia um momento fértil em todo mundo, desde os anos 20 .

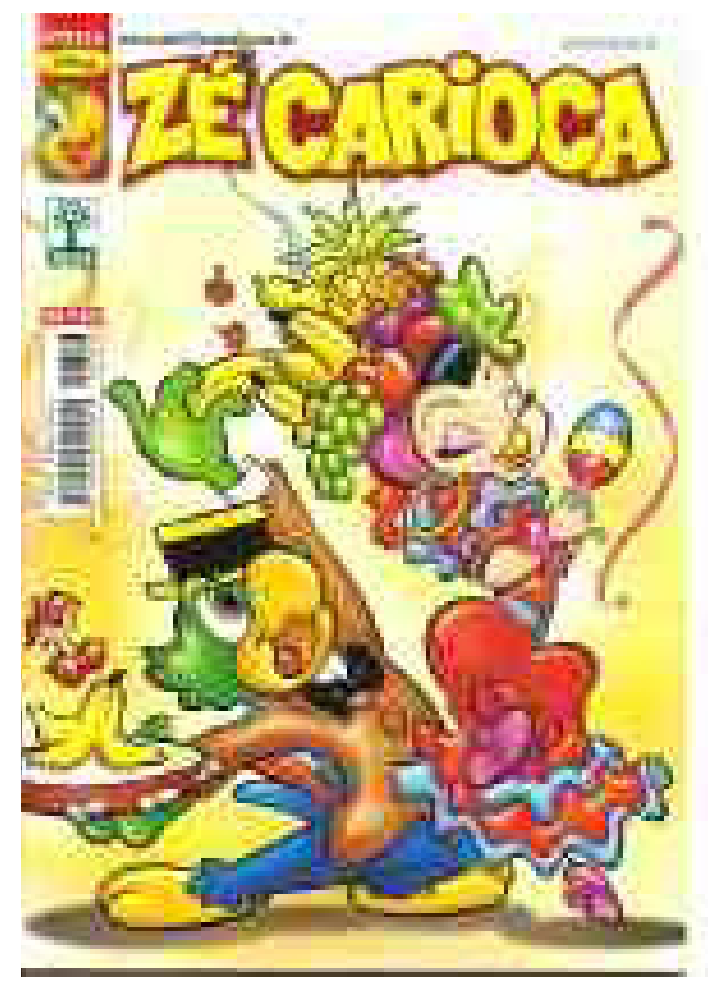

Figura 2: Revista em quadrinhos Zé Carioca, Arte gráfica não identificada, Acervo FUNARTE, 1940

\footnotetext{
${ }^{6}$ A esquiva do desvio ou a ginga é o arredar dissimuladamente ou não; um escapar da ação criando nova, tem sua matriz na cultura afro-brasileira e está presente tanto na Capoeira Angola como na dança do Samba de Gafieira. A ginga reflete no corpo como uma forma de ser e encarar o mundo e atua em um auto arranque espontâneo para estabelecer um novo aparato necessário à ação que se iniciará, subtraindo algo para introduzir outra possibilidade. Este ato mantém a novidade, vivacidade e qualidade do movimento, tornando o desempenho corporal vigoroso.
} 
Há um consenso entre vários pesquisadores quanto ao fato de que foi a atmosfera tensa, gerada pela Primeira Guerra Mundial, que deu impulso decisivo para a dança baseada em ritmos frenéticos tornarse uma das atividades simbólicas preponderantes da vida social. (...) a iconografia antes da guerra, deixara de ser a figura de uma romana vestida com os atributos do progresso. A iconografia da civilização era um sujeito de cabeleira arranhando tangos ao violino (Sevcenko, 1998, p. 58).

Tanto no Brasil, como em outros países, a dança passa a ter maior aceitação; os ritmos, os cantos e as expressões corporais tornam-se intensos e mais vibrantes. 0 maxixe, o bolero e o tango são sucesso nas grandes capitais da cultura mundial como Londres, Paris e Buenos Aires. No Rio, esta aceitação da dança é experimentada pela burguesia carioca que começa a frequentar as gafieiras da Cinelândia e da praça Tiradentes. Danças de origem africana como o lundu, a polca e o maxixe começam a ser aceitos desde o final dos anos 20. Com uma música mais rápida e a proximidade sensual dos corpos nas danças, abre-se a possibilidade de maior descontração, para uma linguagem que passa a ser mais corporal, de mudanças que refletem os novos valores que emergem nesta sociedade moderna. Neste contexto cultural, em um tempo de buscas intensas e também da própria brasilidade, Eros Volúsia desponta como bailarina, professora, coreógrafa e criadora da Dança Brasileira, uma ponte nesta realidade ao mesmo tempo múltipla e contraditória entre a tradição e o popular.

\section{Eros Volúsia}

Eros Volúsia começa a dançar aos quatro anos de idade e a estudar dança acadêmica aos cinco, no Teatro Municipal do Rio de Janeiro, com Maria Olenewa entre outras grandes mestras. A sua primeira aparição pública, aos oito anos de idade, acontece no Teatro Municipal, tendo entre os presentes o então presidente da república Washington Luís. Na ocasião, apresenta-se descalça, com acompanhamento de violão e batucada, uma ousadia incompatível com as tradições elitistas daquele palco, tão tradicional. Executa uma performance que o público não sabe como receber. O silêncio inicial da plateia é quebrado pelo presidente que comanda os aplausos. Eros inicia assim, uma carreira que "a projeta no cenário artístico do país como criadora do nosso bailado popular"... "dancei um samba acompanhada por um conjunto de jovens violinistas" (Volúsia, 1983, p. 44). Mas, a sua história 
começa antes. Nascida em uma família de artistas, Eros Volúsia cresce em ambiente de grande efervescência cultural. A casa de sua família já é frequentada durante gerações por escritores, como Arthur e Aluízio Azevedo, Pardal Mallet, Luiz Murat, Coelho Neto e Olavo Bilac e por grandes músicos, entre os quais CarIos Gomes, Chiquinha Gonzaga, Alberto Nepomuceno e Francisco Braga. Quatro gerações de artistas compõem a sua genealogia. O bisavô materno, um violinista, sua avó Teresa Costa marca época no teatro nacional, tendo mais tarde aderido à radiofonia, sua mãe, Gilka Machado, é a criadora de poemas da literatura nacional e seu pai, também poeta, Rodolfo Machado. No entanto, Eros Volúsia tem outra influência além da artística vivida cotidianamente em casa e nos saraus organizados pela família, a da cultura afro brasileira. E tal influência manifestou-se logo.

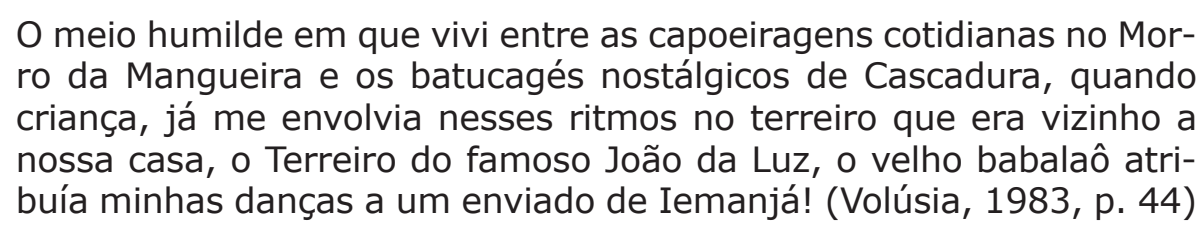

Em sua memória de infância, ela fala de suas danças diferentes, não na origem africana, mas na qualidade da performance afro brasileira. Uma dança dos morros, a capoeira, mais individual e corpórea, e de outra dança dos subúrbios, o batuque, mais coletivo, socializado e ritual. Sua carreira segue de forma meteórica e estruturada em seus estudos de danças clássicas. No entanto, traz em seu corpo também outras memórias, uma performance de dança negra. Este encontro de estéticas marca um diferencial, sendo, vez por outra, comparada a Isadora Duncan, bem como recebendo elogios de Ana Pavlova.

essa garota que acabo de ver se exercitando tem tudo para se tornar uma grande bailarina clássica: boa postura, magnífica cintura, flexibilidade, ballon, firmeza nas piruetas e mãos que falam e são de uma beleza invulgar (Volúsia, 1983, p. 42).

Apesar de aprender a técnica clássica acadêmica, não desenvolve predileção por este gênero e logo passa a realizar recitais de bailados brasileiros. A partir daí, cria coreografias e desenvolve sua tendência para danças nacionalistas e/ou expressionistas, "as que externassem estados d'alma!" (Volúsia, 1983 p. 44). Referindo-se 
ao seu próprio trabalho declara, nesta época: "talvez eu possa traduzir as minhas criações nacionais como: dramáticas, simbólicas e recreativas, todas, no entanto, impregnadas de uma grande dose de expressionismo" (Volúsia, 1983 p. 44).

Na Exposição dos cinco, em fins dos anos trinta, Paschoal Carlos Magno apresenta Eros Volúsia a intelectuais, ocasião em que dança três números: Morte do Cisne, Lenda de um Beijo, Agonia da Saudade. O poeta Augusto Lima, assistindo à dança afirma que: "aquelas pernas inquietas estavam firmando os alicerces do bailado nacional" (Volúsia, 1983 p. 31).

Logo, Luiz Edmundo a convida para ilustrar performaticamente sua conferência, a realizar-se na Escola de Belas Artes, sobre a reconstituição de 46 danças do Brasil Colonial. E, partindo deste convite, Eros Volúsia efetua pesquisa em diversas regiões do Brasil, cujo resultado vai sedimentar o seu método de trabalho, calcado em bailados e danças afro ameríndias. Sobre esta apresentação, Eros Volúsia dá um depoimento da sua performance:

Foi a primeira vez que um bailado acontecia neste lugar (...) quando me exibia em um número de dança fetichista com música autêntica da linha de Umbanda, tive que terminar a dança sem música, pois a maioria dos componentes da orquestra no decorrer da apresentação foi caindo em transe (Volúsia, 1983 p. 44).

Em 1937, já com 23 anos, apresenta-se no Teatro Municipal do Rio de Janeiro, que abre as portas definitivamente para o bailado nacional, com a orquestra do próprio teatro, regida pelo maestro Francisco Mignone. A proposta de Eros Volúsia é de tal forma bem aceita que são criados em estados brasileiros programas escolares por professores de Educação Física chamados de bailados brasileiros. Como cita Eros Volúsia:

Ali se apresentava oficialmente a arte coreográfica característica do Brasil, no setor erudito do balé, por iniciativa do Ministro da Educação Gustavo Capanema. Foram abertas as portas ao bailado característico do Brasil e ninguém mais Ihe podia impedir a ascensão! (Volúsia, 1983 p. 40) 


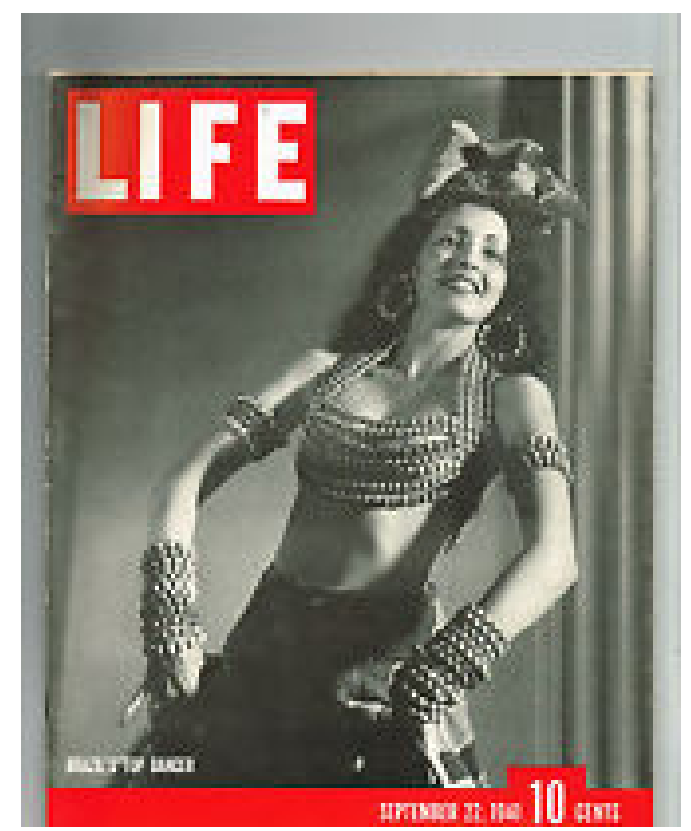

Figura 3: Eros Volúsia, Revista Life Magazine de 22 de setembro de 1941.

A consagração no Brasil, leva-a a ter os seus movimentos copiados por desenhistas de Walt Disney, na criação da personagem namorada de Zé Carioca. O jornalista americano Hart Preston vem ao Brasil fazer uma entrevista com Eros Volúsia para uma matéria da revista Life Magazine.

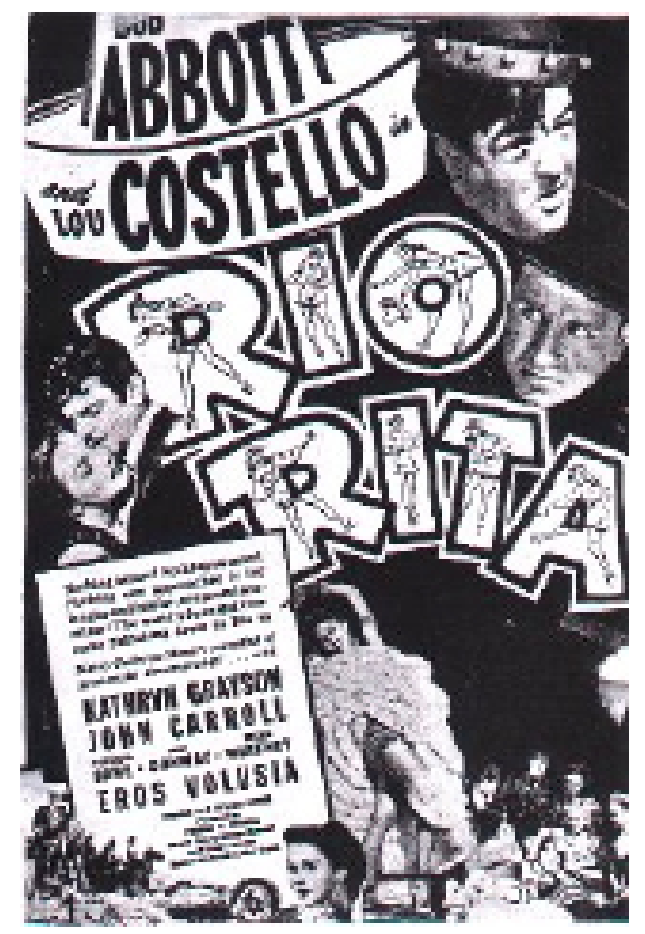

Figura 4: Eros Volúsia no filme Rio Rita, dirigida por S.

Sylvan Simon, fotógrafo não identificado Acervo FUNARTE 1942 
Tal ensaio fotográfico resulta em ser escolhida para a capa da revista e, como consequência, é contratada pela Metro Goldwyin Mayer, para dançar no filme Rio Rita (1942), em Hollywood, quando contracena com Bud Abbotti e Lou Costello?. Em seguida ao sucesso nos Estados Unidos, é convidada pelo governo francês para tomar parte nos festivais de folk-danse franco-brasileiros. Além dos festivais que são realizados no Théâtre des Champs Elysées, dança na Boite Drap D'OR, no Club Champs Elysées e no Cassino D’Enghien. Ainda em Paris, realiza nos Archives Internacionales de la Dance uma conferência sobre o bailado brasileiro, inaugurando a seção de danças brasileiras neste arquivo e tornando-se correspondente do mesmo no Brasil. Um dos seus trabalhos coreográficos mais aplaudidos é Macumba ${ }^{8}$, que os franceses apelidaram a dança dos cabelos, cujo movimento de rotação de cabeça em crescente aceleração é até hoje utilizado por bailarinos brasileiros.

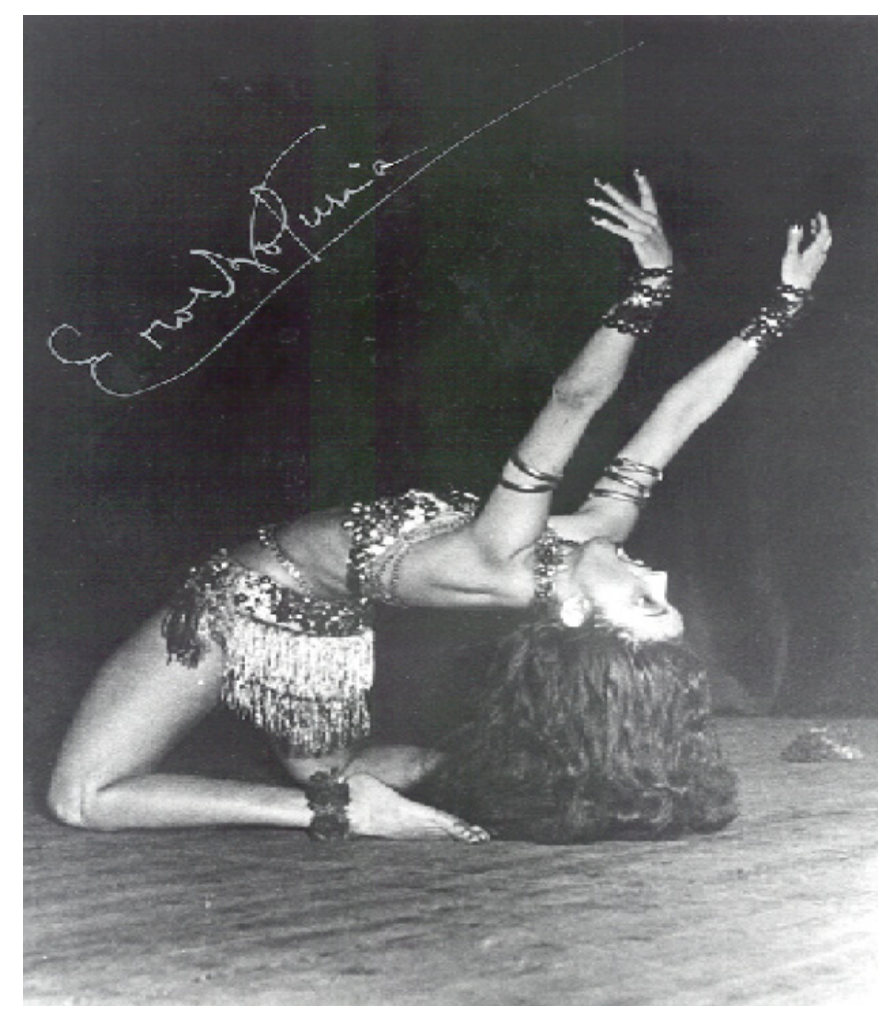

Figura 5: Eros encenando a sua coreografia solo Macumba (s/ano), fotógrafo não identificado, Acervo FUNARTE

\footnotetext{
${ }^{7}$ Eros Volúsia também atuou em vários filmes nacionais como, por exemplo: Favela dos Meus Amores (1935), Samba da Vida (1937), Caminho do Céu (1943), Romance Proibido (1944) e Pra Lá de Boa (1949). ${ }^{8}$ A coreografia Macumba não tem data de sua criação coreográfica.
} 
Iniciada uma trajetória que poderia ser semelhante à de Carmem Miranda, no entanto, opta por voltar e sedimentar seu curso já iniciado no Brasil. De volta ao Rio, no Cassino Copacabana lança a música Tico-Tico no Fubá, em andamento mais acelerado, que torna a música conhecida no mundo inteiro. Antes de suas viagens internacionais iniciarem, Eros Volúsia havia sido nomeada professora do Ministério da Educação, no Serviço Nacional do Teatro. Em seu retorno, passa a dedicar-se à formação do seu grupo de bailado. Como professora do antigo S.N.T., cria o Curso de Coreografia, com a finalidade de fornecer elementos para o teatro musicado nacional. O curso de Ballet do S.N.T. é ministrado, através de aulas práticas, sem contudo desprezar o lado teórico. Os alunos recebem um preparo técnico corporal, a dança acadêmica, segundo Volúsia, "método universal indispensável a preparação do corpo para aprender qualquer ensinamento artístico coreográfico" (Pereira, 2004, p. 34). Neste curso, Eros abole mais uma prática, considerada normal nas Escolas de Dança no Brasil, e permite que bailarinos negros, mulatos ou pardos possam fazer aulas e integrar a sua companhia de bailados. O término desta distinção racial é copiado por diversas escolas. Deste curso, inúmeros talentos saíram, entre estes brancos, negros e mulatos, destacando-se artisticamente nos Teatro de Revista, no Corpo de Baile do Teatro Municipal Rio de Janeiro e no cinema nacional. Dentre tantos, citamos: Sebastião Araújo, Gilberto de Assis e Mercedes Baptista. Sua ação no Grupo Coreográfico, bem como suas viagens e palestras sobre sistematização da coreografia nacional têm sempre a proposta da implantação, sistematização e desenvolvimento de uma dança que Eros chamava de Dança Nacional. Neste sentido, exibe o primeiro Ballet brasileiro, com alunos da sua escola, conquistando o prêmio Medalha de Ouro, concedido pela Associação de Críticos Teatrais para a melhor realização coreográfica do ano. São três os bailados dançados e se intitulam: Recordações do Congo, Taieras e Fandango. Recolhendo em pesquisa temas populares de origem afro- brasileira e ameríndia e transformando-os em criações coreográficas, Eros Volúsia transporta para o palco um estilo novo de dança e performance, de ritmo e de raízes brasileiras. Em reflexões sobre dança brasileira, em específico o Maracatu, escreve:

Sentia que não podia me restringir ao método acadêmico (...) o amor ao ritmo brasileiro e às danças que exprimissem estados d'alma exigiam para mim maior campo de ação (...) fugindo ao comum dos nossos ritmos que se incorporam, quase todos de origem negra, 
nas pernas e quadris dos executantes, o maracatu é uma dança de espáduas, um movimento giratório de ombros, que os pescoços acompanham em elastecimentos musicais, enquanto os pés deslizam, marcando apenas o compasso. Voltas rápidas de corpos eretos são executadas de momento em momento (Volúsia, 1983, p. 81)

O maracatu é descrito por Eros Volúsia com um tom de exaltação porque a dança, segundo ela, é um dos resquícios da "congada - a mais fecunda criação coreográfica dos negros no Brasil" (Lima, 2000, p. 61).

De sua obra de pesquisa, estilização e recriação coreográfica das danças ameríndias e da herança afro brasileira podemos afirmar que Eros transpõe fronteiras sociais, políticas e étnicas. Através da performance das danças criadas, a tradição é apreendida, recriada e transmitida sendo a sua fixação e permanência estabelecidas na coreografia artística. De sua dança pessoal, Eros Volúsia torna-se a própria imagem da garota linda, em trajes sumários, um padrão do mundo hollywoodiano e da sensualidade, dos

musicais da cinematografia americana dos anos 30 até os meados dos anos $50(\ldots)$ seu sucesso era estrondoso porque fundia as linguagens mais expressivas da ação e da modernidade, o esporte, a dança, o glamour, a coordenação coletiva e o primado do destino individual" (Sevcenko, 1998, p. 251).

Tules sedas paetês, tecidos dourados e prateados, colares, braceletes, pulseiras e tiaras, corpetes, saltos altos - a certeza que o prazer existia e que era possível desejá-lo.

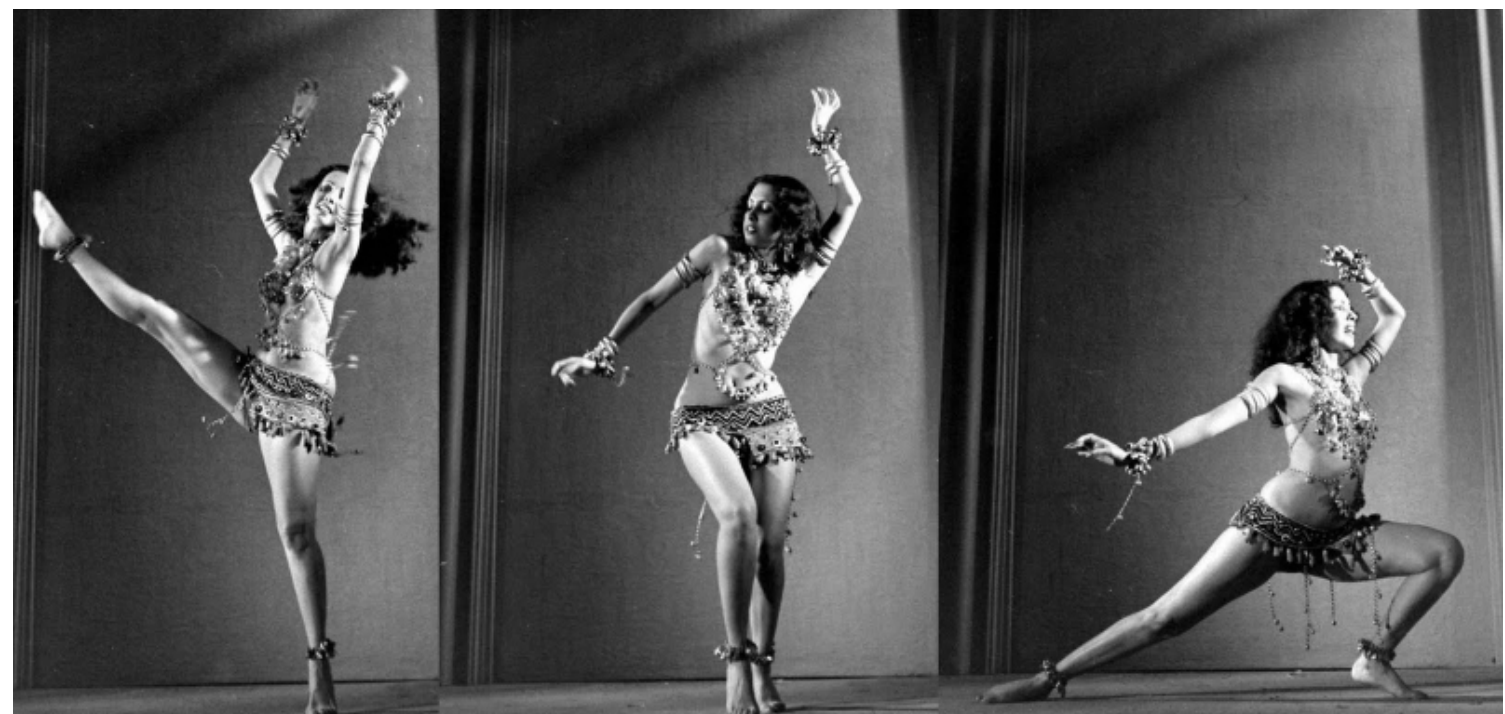

Figura 6: Estudo fotográfico para a Revista Life Magazine, fotógrafo não identificado Acervo FUNARTE 


\section{A Dança}

O que podemos perceber é que Eros Volúsia, movida pela questão da construção de um pensamento nacionalista brasileiro e pelo interesse de entender e conhecer mais as danças brasileiras, escolhe e é escolhida para ser a representante deste movimento. Em consequência acaba por estabelecer, em sua pesquisa, um movimento de procura em dois sentidos diferentes, para dentro do Brasil e para o exterior. Eros Volúsia viaja pelo Brasil, estuda nossa cultura, à época ainda chamada de folclore, e pesquisa uma diversidade de danças, interessada em perceber, em nossas tradições culturais, o simbólico do corpo e suas virtuosidades performáticas. Tal qual Mário de Andrade, não pretende ir para o passado, quer entender o tempo presente a partir da cultura popular; a brasilidade corporal, as relações dos corpos e dos aspectos vivos do imaginário no presente que, em todas as culturas dão sabedoria, nexo e conhecimento. Quer entender a tradição no que ela tem de atual e de vivo, por sua praxis. Em uma visão performática, associa o corpo num acontecimento social e espetacular, na perspectiva de entender uma forma de ser corporalmente, de se comportar, de agir, de falar, de cantar e de se enfeitar. Uma tradição cambiante, que Mário de Andrade denominava de "tradições móveis" e de "lição para meditar, não para repetir" (Andrade, 1992, p. 32). Assim, Eros Volúsia, tal qual os Modernos de São Paulo, entende o passado como caminho, jamais como permanência e, tal qual os intelectuais do Rio de Janeiro percebe a riqueza da circulação de bens culturais ocorrida da relação entre intelectuais, artistas e populares, isto é, uma performance de criação estético cultural, distintamente com viés afro descendente.

Percebe-se que sua proposta, através do contato e da troca cultural entre as várias regiões brasileiras, estabelece o fundamento de uma dança brasileira, uma dança que revela comportamentos emergentes fundadores da nossa identidade afro ameríndia. Da mesma forma, viaja para o exterior, num movimento de antropofagia moderna, na procura de ingerir, devorar corpos e espíritos e digerí-los por metabolismo em semelhantes, não iguais e portanto, distinguíveis deles. A digestão será seletiva, a metáfora modernista da antropofagia, que implica na recriação das ideias vindas do exterior, como se fossem nossas, mas passadas por um crivo seletivo - do canibalismo à assimilação. Desta forma, dialoga em suas danças o rural e a cultura negra urbana e ocidental, imbrica sua técnica clássica de bailarina 
do Teatro Municipal do Rio de Janeiro com o fruto de sua pesquisa. Aproxima o erudito europeizado e o popular rural e o urbano negro, em interessantes danças para o palco, em livre recriações de danças tradicionais como congados, reisados, maxixes e batucadas.

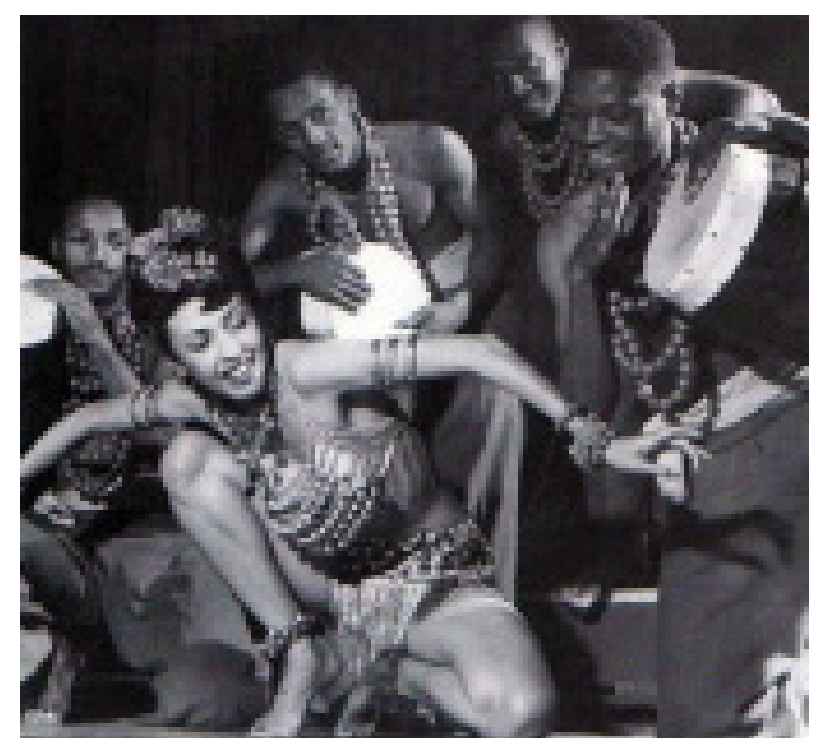

Figura 7: Coreografia Macumba de Eros Volúsia, s/d, fotógrafo não identificado, Acervo FUNARTE

Eros Volúsia, por sua laboriosa procura aos temas brasileiros também se revela uma devoradora de nossas peculiaridades sócio-culturais, ao buscar formas concretas de expressões culturais, partindo de fragmentos, para integrá-las e reinterpretá-las dentro de uma perspectiva mais ampla. Segundo Ortiz,

\begin{abstract}
Neste sentido, (...) a cultura afro e ameríndia não é simplesmente vivenciada na sua particularidade, mas o singular de cada uma passa a definir uma instância mais generalizada de conhecimento. Ao integrar um todo coerente as peças fragmentadas da história africana e ameríndia, os intelectuais constroem uma identidade que unifica os atores que se encontravam anteriormente separados. A identidade é neste sentido elemento de unificação das partes, assim como fundamento para uma ação política (...) orientando-os no sentido de um movimento social" (Ortiz, 2008, p. 54).
\end{abstract}

Eros processa uma incorporação de elementos advindos do contexto tradicional popular, no sentido de uma apropriação retradicionalizada. Ao colocar-se como participante na posição de refletir sua própria cultura, seus experimentos implicam em incontestável produto cultural, resultante de uma variada cadeia de encontros 
com a identidade brasileira. Tal mergulho permite uma leitura cênica do material histórico, através de desempenhos performáticos que recriam na encenação uma produção elegante, mesmo que com uma certa euforia modernista. Como consequência desenvolve um jeito mais livre de dançar, num súbito relevo do psiquismo, como gostava de afirmar e, sobretudo, pensar a complexidade do nosso país.

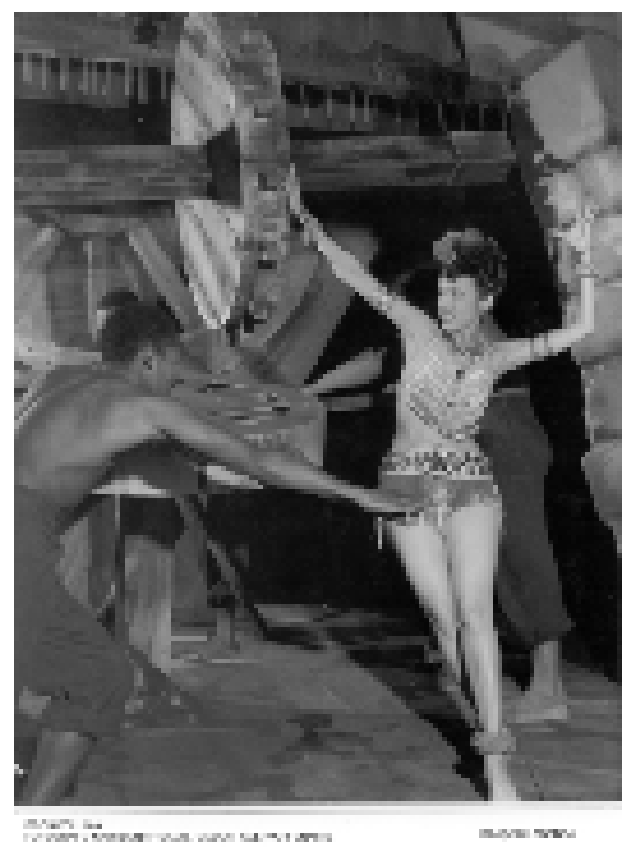

Figura 8: Eros Volusia s/d., fotógrafo não identificado, Acervo FUNARTE

Uma artífice empenhada num jogo de construção simbólica, assume o ser brasileiro, enraizada em sua cultura tropical, cabocla e mutante e com forte ar fantasista de identidade nacional-popular modernista. Sua estética pode até assemelhar-se a um dançar arquétipo adormecido no inconsciente, no entanto, sua dança não está submetida a um simples impulso irrefletido, nem é o eco de um passado. Ao trazer para a sua pele tais movimentos, é antes o inverso: a explosão de uma imagem presente, atual, sendo assim uma novidade, mesmo que sua performance aconteça de uma ontologia direta da dança. Eros estuda a natureza da dança, a existência e a realidade desse povo e momento brasileiro. É nesse contexto que trabalha coreograficamente para a criação da Dança Brasileira. A bailarina dança e cria, então, na essência do ser, porque procura categorizar o que é essencial e fundamental e, por isso, suas imagens seduzem. E seduzem não porque sejam fenômenos intencionais de uma sedução mas, porque também determinam a sua 
presença na ação, pode-se encontrar assim um alcance para as tensões e inversões a que teve que se submeter no decorrer desse processo. Ao nível da sua performance poética, a dualidade da artista e sua pesquisa é matizada, aclarada, incessantemente ativa em suas inversões. Logo, a bailarina, "na novidade de suas imagens, é origem de linguagem" (Bachelard, 2008, p. 187).

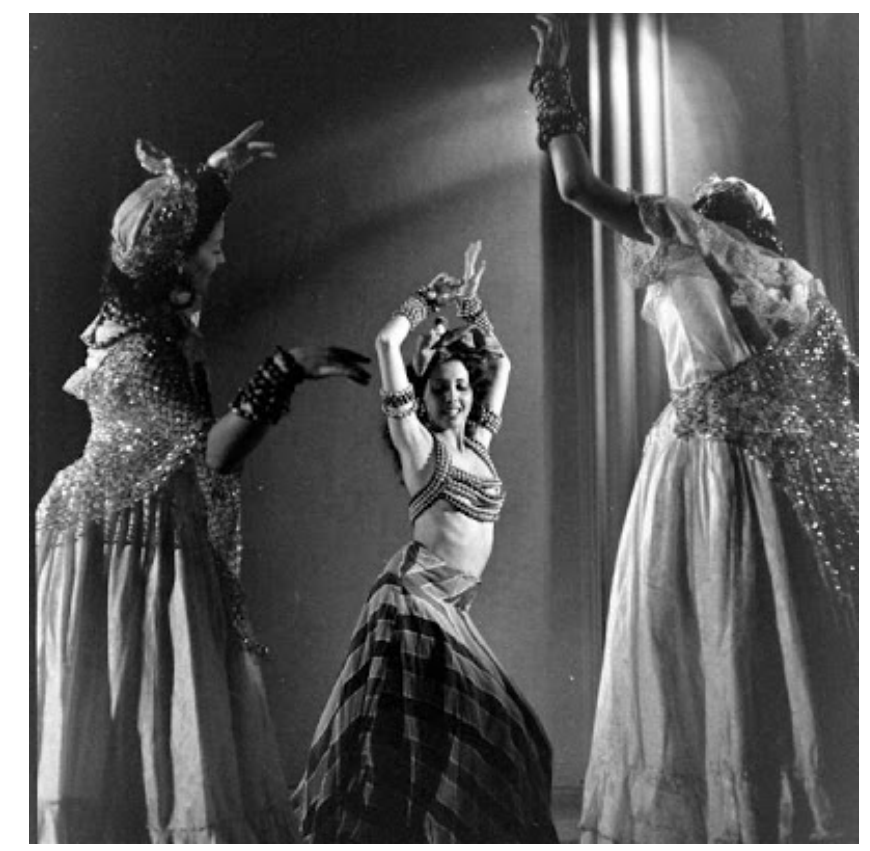

Figura 9: Eros Volusia s/d., fotógrafo não identificado, Acervo FUNARTE

Come escolhendo o que Ihe interessa e, nessa seleção, cria uma dança para o mito modernista e a identidade nacional que se insinua e prossegue viva em sua jornada até o contemporâneo e em constantes atualizações. Mesmo com algumas cômodas reduções de conservadorismo romântico, deixa um legado artístico perene de dança mestiça, refúgio sentimental da brasilidade da época. Como tal, esse legado se desdobra em processos narrativos do corpo, nas técnicas de movimento, enfim, nas formas sensíveis de utilizar o corpo. Logo, este corpo que dança torna-se uma forma de tocar e ao mesmo tempo indica um ato poético em si, onde se pode alterar o valor já atribuído, trazendo novos sentidos, pervertendo, traindo e flexibilizando a aparente realidade. Em uma encenação dançada, Eros aponta com agudeza sentidos e raízes de uma possível identidade nacional. Mais ainda, nos deixa, além do legado coreográfico para a cena da Dança, um importante legado ${ }^{9}$ documental, de poética e dança criativa brasileira.

\footnotetext{
${ }_{9}$ Em 2002, a Universidade de Brasília (UNB) criou o Centro de Documentação e Pesquisa Eros Volúsia, vinculado ao Departamento de Artes Cênicas. Em 2004, Roberto Pereira, professor de História da Dança e crítico de dança do Jornal do Brasil, publicou a biografia intitulada Eros Volúsia a criadora do bailado nacional - perfis do Rio.
} 


\section{Bibliografia}

ANDRADE, Mário de. Danças dramáticas do Brasil. Belo Horizonte/Brasília: Itatiaia, Instituto Nacional do Livro, Fund. Nacional Pró Memória, 1992.

BACHELARD, G. A Poética do Espaço. São Paulo: Martins Fontes, 2008.

LIMA, Nelson. A dança de Eros Volúsia. In: LOPES, Antonio Herculano. (Org.). Entre Europa e África: a invenção do carioca. Rio de Janeiro: Topbooks, 2000.

MOTA, Carlos Guilherme. Ideologia da Cultura Brasileira (1933-1974). São Paulo: Ática, 1990.

MOURA, Roberto. A indústria cultural e o espetáculo-negócio no Rio de Janeiro. In: LOPES, Antonio Herculano. (Org.). Entre Europa e África: a invenção do carioca. Rio de Janeiro: Topsbooks, 2000.

ORTIZ, Renato. Cultura Brasileira \& Identidade Nacional. São Paulo: Brasiliense, 2008.

PEREIRA, Roberto. Eros Volúsia a criadora do bailado nacional - perfis do Rio. Rio de Janeiro: Relume Dumará, 2004.

SALIBA, Elias Thomé. A dimensão cômica da vida privada na República. In: SEVCENKO, Nicolau; NOVAIS, Fernando A. (Org.). História da Vida Privada no Brasil. São Paulo: Cia das Letras, 1998.

SEVCENKO, Nicolau. A capital irradiante: técnica, ritmos e ritos do Rio. In: SEVCENKO, Nicolau; NOVAIS, Fernando A. (Org.). História da Vida Privada no Brasil. São Paulo: Cia das Letras, 1998.

TINHORÃO, José Ramos. Pequena história da música popular. São Paulo: Art Editora, 1998.

VELLOSO, Monica. Que cara tem o Brasil? As maneiras de pensar e sentir o nosso país. Rio de Janeiro: Ediouro, 2000.

VOLÚSIA, Eros. Eu e a dança. Rio de Janeiro: Revista Continente, 1983.

ZENICOLA, Denise. The Slaves. In: A Gazelle of the Savannah. Abuja: Alpha Crownes

Publishers, 2012. 